Article

\title{
Quality of life and subjective well-being modeling of pulmonary tuberculosis patients
}

\author{
Dhian Satya Rachmawati, ${ }^{1,2}$ Nursalam Nursalam, ${ }^{3}$ Rachmat Hargono, ${ }^{1}$ \\ Bambang Widjanarko Otok ${ }^{4}$
}

${ }^{1}$ Doctoral Program of Public Health, Faculty of Public Health, Universitas Airlangga, Surabaya; ${ }^{2}$ Sekolah Tinggi Ilmu Kesehatan Hang Tuah Surabaya; ${ }^{3}$ Faculty of Nursing, Universitas Airlangga, Surabaya; ${ }^{4}$ Department of Statistics, FMKSD, Institut Teknologi Sepuluh Nopember, Surabaya, Indonesia

\begin{abstract}
Background: Patients suffering from pulmonary tuberculosis and their family are often faced with psychosocial problems that cause stress, such as loss of hope, sleep disorders and interruption in period of rest. Therefore, this study aims to analyze the Quality of Life (QoL) and Subjective Well Being (SWB) of pulmonary TB patients and the affecting factors.

Design and Methods: An analytical observational design with a cross sectional approach was used and a total of 73 respondents were randomly selected from 89 patients with pulmonary TB. Furthermore, a questionnaire was used as study instrument and data analysis was carried out using Partial Least Square.

Results: The results showed that with the Partial Least Square Structural Equation Modeling (PLS-SEM) approach, the SWB and QoL models are fit models based on R2, Q2 values. Furthermore, patient characteristics, patient factors and family factors influence subjective well-being (SWB) and quality of life (QoL). Meanwhile, the dominant influence on SWB was the patient factor, while on QoL it was the family factor.

Conclusion: This model will be the basis for further studies on how to care for pulmonary tuberculosis patients and their families in order to improve the quality of life and patient acceptance of their sick conditions.
\end{abstract}

\section{Introduction}

Pulmonary tuberculosis (TB) patients and their family are often faced psychosocial problems that cause stress, such as loss of hope, sleep disorders and restless disorders. ${ }^{1}$ Furthermore, depression may occur due to the stigma that is felt at the beginning of diagnosis..$^{2,3}$ Consequently, the targets of nursing care are families with health problems. Therefore, this study focuses on families with one of its members suffering from TB. The disease is also capable of causing disturbances in the vitality of life, social function, emotional state and general mental health. Stress and anxiety are very influential on pulmonary TB patients because it greatly affects the self-concept and self-acceptance, which is related to happiness, well-being and life satisfaction. The role of the family in taking care and providing support to the patients is very important, in order to maintain the optimum level of patient health when facing the disease. ${ }^{4}$ Previous studies also stated that majority of pulmonary TB patients do not have a social support system and there is poor compliance. ${ }^{1}$ Therefore, good support and care from the family becomes a consideration in providing special attention to the daily routine of patients with pulmonary TB. ${ }^{5}$ This study aims to analyze the quality of life and subjective well-being of pulmonary TB patients and the affecting factors.

TB is the ninth cause of death in the world and also one of the main causes of death with a single infectious agent, ranked above HIV/AIDS. In 2016, about 1.3 million deaths by TB among HIVnegative individuals (down from 1.7 million in 2000) and an additional 374,000 deaths among HIV-positive individuals was recorded. Furthermore, it was estimated that about 10.4 million individuals consisting of $90 \%$ adults, $65 \%$ men, $10 \%$ living with HIV (74\% in Africa) and $56 \%$ in five countries, namely India, Indonesia, China, Philippines and Pakistan, ${ }^{6}$ suffer from TB based on the 2016 Global TB Report. The national prevalence of pulmonary tuberculosis cases in Indonesia in 2010 was 285 per 100,000 population and mortality rate was estimated at 1.4 million plus an additional 0.4 million among individuals with HIV. Although, the number of deaths due to tuberculosis decreased by $22 \%$ between 2000 and 2015 , it remained the $10^{\text {th }}$ highest cause of death in the world in 2015. Indonesia ranks fifth in the world, after India, China, South Africa, and Nigeria, in terms of prevalence of TB. The WHO Global Tuberculosis Report (2016) stated that the incidence of tuberculosis in Indonesia in 2015 was around 395 cases/100,000 population, mortality rate was $40 / 100,000$ population (excluding HIV patients with tuberculosis) and HIV patients with tuberculosis was $10 / 100,000$ population. According to the prediction model calculation based on the results of the 2013-2014 tuberculosis prevalence survey, the estimated tuberculosis prevalence in 2015 and 2016 were 643 and 628 per 100,000 population.

Significance for public health

Patients with pulmonary TB experience physical and psychosocial changes during the course of treatment. Psychological issues may occur due to the stigma that is felt at the start of diagnosis. These factors which cause stressful conditions, lead to reduction in the quality of life and acceptance of sufferers and their families. This paper describes the Quality of Life (QoL) and Subjective Well Being (SWB) among TB patients. 
In 2016 the number of tuberculosis cases was discovered to have increased to 351,893 , when compared to all tuberculosis cases in 2015 which was over 330,729 . The highest number of reported cases is in provinces with large populations, namely West, East and Central Java. The number of cases in the three provinces were about $44 \%$ of the total number of new cases in Indonesia. ${ }^{7}$ Surabaya is the second largest city in Indonesia and in 2015, the number of new cases in the city was 2,330 , BTA + cure rate was $70.43 \%$, and success rate of treatment was $79.21 \%{ }^{8}$

Patients with pulmonary tuberculosis experience physical changes, usually marked by changes in physical conditions, making them appear thinner, pale and decrease in physical abilities and conditions like this tend to affect their self-concept. Furthermore, they tend to experience stressful and irritable events due to social disability and avoidance by the community. In addition, it stimulates their emotional feeling, making them feel useless, hopeless, withdrawn, like dying and giving up..$^{9}$ Tuberculosis sufferers see no meaning in life because they do not get social support from their surroundings, therefore, they feel isolated in their family and environment. ${ }^{10}$ This condition of losing the meaning of life experienced by TB sufferers is a negative form of subjective well-being. Subjective well-being (SWB) is a form of evaluation on an individual to measure the psychological well-being which is a unity of life that includes good feelings, life satisfaction and feelings (moods and emotions), both positive and negative, which affect individual's life to feel happy and prosperous.

$\mathrm{TB}$ is an infectious and contagious disease of the vital tube. It is caused by the Mycobacterium tuberculosis bacillus which is 1-4 $\mathrm{mm}$ long and 0.3 to $0.6 \mathrm{~mm}$ thick. ${ }^{11}$ This disease spreads quickly to vulnerable individuals and those with weak immune system. The factor that influences its incidence is age, because the highest incidence of tuberculosis was recorded among the productive age. The next factor is that more common among the males than females, due to bad habits such as smoking, which may also be categorized as an influencing factor. ${ }^{12}$ Other factors include the environment, employment and economic status. These factors affect the physiological conditions of patients with clinical symptoms, namely chronic cough ( $>3$ weeks), sputum production, no appetite, decreased body weight, fever, night sweats ${ }^{1}$ and hemoptysis. ${ }^{13}$ The condition affects patients' emotions, making them feel helpless, rejected, guilty, inferior and withdraw from others for fear that the disease would transmitted to others. ${ }^{14}$ Pulmonary tuberculosis is a contagious disease, that affects the social status, which in turn becomes a stressor for the sufferer due to the negative treatment received from the environment and family. Furthermore, it has an impact on the quality of life of such individual. Therefore, social, spiritual and psychosocial supports are needed by TB sufferers to improve quality of life, because it affects human behavior, such as reducing anxiety, helplessness and hopelessness, which in turn is able to improve health status. ${ }^{15}$ Based on the Global Tuberculosis Report in 2016, Indonesia ranks second for the number of patients with TB. Various efforts have been made to eradicate this pulmonary TB in order to succeed in the Indonesia free TB 2050 program. In this study, indicators and variables that affect SWB and QoL were theoretically examined.

\section{Design and Methods}

An analytical observational design with a cross sectional approach was used, which involved 73 respondents that were randomly selected from 89 patients with pulmonary TB at a public health center in the city of Surabaya. The WHO quality of life
(QoL) instruments were used to measure the quality of life of patients with pulmonary tuberculosis, while those used to measure subjective well-being include: 1) Satisfaction with Life Scale (SWLS), a questionnaire used to measure cognitive effect, namely one's life satisfaction and 2) Scale of Positive and Negative Experience (SPANE), a questionnaire used to measure a person's affective effect.

This study was approved in the form of a permit from the Surabaya City Health Office Number: 072/17674 / 436.72 / 2018 on the basis of the permit recommendation from the authorization of the Surabaya city government, which provides survey permits to the community (Bakesbang Pol and Linmas). Furthermore, a statement letter with ethical health study number: PE/69/VII/KEPK/SHT was obtained from the Health Research Ethics Committee of Stikes Hang Tuah, Surabaya Indonesia. Data analysis was carried out using the partial least squares structural equation modeling (PLS-SEM). In this study, indicators and variables that affect SWB and QoL were theoretically examined. This was carried out by arranging them into theoretical models that will be proven by field data into data-based model. PLS does not assume a certain distribution for parameter estimation, therefore parametric techniques to test parameter significance were not required. Furthermore, the magnitude of the structural path coefficient of the stability of this estimate was evaluated using t-test statistics obtained from the bootstrapping procedure. ${ }^{16}$ Modeling using Partial Least Square (PLS) with the following steps:

1. Outer model. It includes the validity test seen from the results of loading factors and the reliability test seen from the value of composite reliability. The indicator is declared valid when it has a factor loading value $>0.5$ and reliable when the composite reliability value is $>0.6$.

2. Inner model. This is seen from the results of the inner weight value which tests the study hypothesis through the t-test on the bootstrap sample and the goodness of fit model. A model is declared as having goodness of fit when it has a $R$-Square value $>0$ and a Q2 value of 1- - (1 - R12) (1 - R22) (1- R32)> 0.35 giving high accuracy.

The hypothesis in this study (Figure 1) includes: 1) Patient characteristics (PC) have significant influence on SWB; 2) Patient

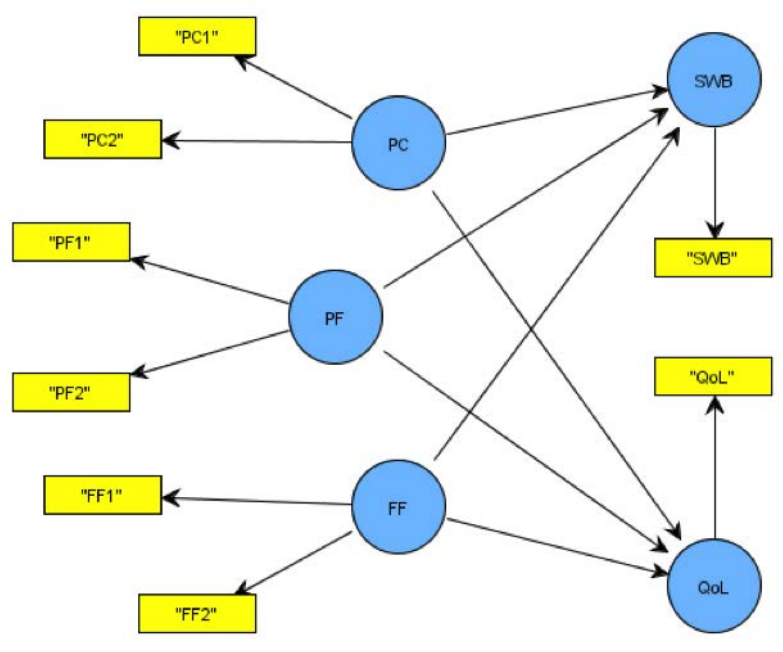

Figure 1. Conceptual model of SWB and QoL of lung TB patients. PC, patient characteristics; FP, patient factor; FF, family factor; SWB, subjective well-being; QoL, quality of life. 
factor (FP) has a significant influence on SWB; 3) Family factors (FF) have a significant influence on SWB; 4) Patient characteristics have significant influence QoL; 5) Patient factor has a significant influence on QoL; and 6) Family factors have a significant influence on QoL.

\section{Results and Discussions}

The respondents of this study were patients with pulmonary tuberculosis still with treatment at one of the public health centers in the city of Surabaya. A total number of 73 individuals were selected based on the characteristics on Table 1. The demographic data showed that the respondents comprised of 38 (52.1\%) females and $35(47.9 \%)$ males. Furthermore, out of the 73 respondents, 23 were aged $46-60$ years $(31.5 \%), 20$ aged $15-30$ years $(27.4 \%), 18$ aged $31-45$ years $(24,7 \%)$ and 12 aged $47-75$ years $(16.4 \%)$. The occupation of the respondents includes self-employed $38(52.1 \%)$, housewives $26(35.6 \%)$, not working $8(11.0 \%)$, other jobs $1(1.4 \%)$.

Respondents with the latest elementary, high school, junior high school, undergraduate education were 34 (46.6\%), 15 $(20.5 \%), 11(15.1 \%)$ and $3(41 \%)$, respectively, while those with no education at school were $10(13.7 \%)$. Pulmonary tuberculosis patients knowledgeable about the disease problem were 58 (79.5\%), while 15 were less familiar with the disease $(20.5 \%)$. Based on emotional levels, pulmonary TB patients with normal emotional levels were 26 (35.6\%), light stress were $30(41.1 \%)$, moderate stress was $(12.3 \%)$, severe stress was $5(6.8 \%)$ and very heavy stress was 3 (4.1\%). Based on social support, pulmonary TB patients with frequent social support was 36 (49.3\%), social support very often was $30(41.4 \%)$ and social support sometimes was $7(9.6 \%)$. The number of respondents in this study were 73 with details of $31(42.5 \%)$ implementing family health care functions with a functional category, $27(37.0 \%)$ implementing health care functions with a sufficiently functioning category and $15(20.5 \%)$ in the lacking/not functioning category.

Respondents in this study were 73 respondents with details of $47(64.4 \%), 15(20.5 \%), 9(12.3 \%)$ and $2(2.7 \%)$ in the high, average, below average and very high category of subjective wellbeing, respectively. Furthermore, respondents with good quality of life were $(68.5 \%)$, while those with less quality of life were 23 $(31.5 \%)$.

The measurement models consisted of validity and reliability test. Detail of results is presented in the Table 2, which shows the loading factors value and T-statistics of each indicator in latent variables of PC, FP and FF. It was discovered that the loading value and T-Statistics of all indicators in each latent variable were greater than 0.5 and the $\mathrm{T}$-table $=1.96$, therefore all indicators were
Table 1. Demographic data of respondents.

\begin{tabular}{|c|c|c|}
\hline & Frequency & $\%$ \\
\hline $\begin{array}{l}\text { Gender } \\
\text { Male } \\
\text { Female }\end{array}$ & $\begin{array}{l}42 \\
31\end{array}$ & $\begin{array}{l}57.5 \\
42.5\end{array}$ \\
\hline $\begin{array}{c}\text { Age (years) } \\
15-30 \\
31-45 \\
46-60 \\
31-75 \\
\end{array}$ & $\begin{array}{l}20 \\
18 \\
23 \\
12\end{array}$ & $\begin{array}{l}27.4 \\
24.7 \\
31.5 \\
16.4\end{array}$ \\
\hline $\begin{array}{l}\text { Occupations } \\
\text { Self-employed } \\
\text { Housewife } \\
\text { Other occupation } \\
\text { Not working }\end{array}$ & $\begin{array}{l}26 \\
38 \\
1 \\
8\end{array}$ & $\begin{array}{c}35.6 \\
52.1 \\
1.4 \\
11.0\end{array}$ \\
\hline $\begin{array}{l}\text { Education } \\
\text { No schooling } \\
\text { lementary } \\
\text { Junior high school } \\
\text { Senior high school } \\
\text { Undergraduate/higher educatio }\end{array}$ & $\begin{array}{c}2 \\
14 \\
17 \\
36 \\
4\end{array}$ & $\begin{array}{c}2.7 \\
19.2 \\
23.3 \\
49.3 \\
5.5\end{array}$ \\
\hline $\begin{array}{l}\text { Pulmonary TB knowledge } \\
\text { Good } \\
\text { Less }\end{array}$ & $\begin{array}{l}58 \\
15\end{array}$ & $\begin{array}{l}79.5 \\
20.5\end{array}$ \\
\hline $\begin{array}{l}\text { Emotional status } \\
\text { Normal } \\
\text { Mild stress } \\
\text { Moderate stress } \\
\text { Heavy stress } \\
\text { Very heavy stress } \\
\end{array}$ & $\begin{array}{c}26 \\
30 \\
9 \\
5 \\
3\end{array}$ & $\begin{array}{c}35.6 \\
41.1 \\
12.3 \\
6.8 \\
4.1\end{array}$ \\
\hline $\begin{array}{l}\text { Social status } \\
\text { Lack of social support } \\
\text { Social support is rare } \\
\text { Social support occasionally } \\
\text { Frequent social support } \\
\text { Social support always }\end{array}$ & $\begin{array}{c}0 \\
0 \\
7 \\
36 \\
30\end{array}$ & $\begin{array}{c}0 \\
0 \\
9.6 \\
49.3 \\
41.1\end{array}$ \\
\hline $\begin{array}{l}\text { Family stress } \\
\text { Light } \\
\text { Moderate } \\
\text { High } \\
\end{array}$ & $\begin{array}{c}51 \\
22 \\
0\end{array}$ & $\begin{array}{c}69.9 \\
30.1 \\
0\end{array}$ \\
\hline $\begin{array}{l}\text { Family health care function } \\
\text { Less / none } \\
\text { Simply functioning } \\
\text { Function }\end{array}$ & $\begin{array}{l}15 \\
27 \\
31\end{array}$ & $\begin{array}{l}20.5 \\
37.0 \\
42.5\end{array}$ \\
\hline $\begin{array}{l}\text { Subjective well-being (SWB) } \\
\text { Below average } \\
\text { Average } \\
\text { Height } \\
\text { Very high }\end{array}$ & $\begin{array}{c}9 \\
15 \\
47 \\
2\end{array}$ & $\begin{array}{c}12.3 \\
20.5 \\
64.4 \\
2.7\end{array}$ \\
\hline $\begin{array}{l}\text { Quality of life (QoL) } \\
\text { Poor } \\
\text { Good }\end{array}$ & $\begin{array}{l}23 \\
50\end{array}$ & $\begin{array}{l}31.5 \\
68.5\end{array}$ \\
\hline
\end{tabular}

Table 2. Validity and reliability test of indicator on latent variable.

\begin{tabular}{|c|c|c|c|c|}
\hline \multirow[t]{2}{*}{ Variable } & \multirow[t]{2}{*}{ Indicator } & \multicolumn{2}{|c|}{ Validity } & \multirow{2}{*}{$\begin{array}{l}\text { Composite } \\
\text { reliability (C-R) }\end{array}$} \\
\hline & & Loading factor & T-statistics & \\
\hline \multirow[t]{2}{*}{ Characteristic of patient (PC) } & Age (PCl) & 0.756 & 5.128 & \multirow[t]{2}{*}{0.698} \\
\hline & Knowledge (PC2) & 0.543 & 2.713 & \\
\hline \multirow{2}{*}{ Patient factor (FP) } & Emotional status (PF1) & 0.589 & 3.592 & \multirow[t]{2}{*}{0.708} \\
\hline & Social status (PF2) & 0.729 & 5.713 & \\
\hline \multirow{2}{*}{ Family factor (FF) } & Family stress (FF1) & 0.812 & 9.468 & \multirow[t]{2}{*}{0.811} \\
\hline & Health care function (FF2) & 0.670 & 3.437 & \\
\hline SWB & Subjective well-being & 1.000 & & \\
\hline QoL & Quality of life & 1.000 & & \\
\hline
\end{tabular}


said to be valid and significant in forming latent variables. Based on reliability, Table 1 also shows that the variable produced a Composite Reliability (C-R) value above the cut-off value of 0.6 , therefore all latent variables were said to be reliable.

Structural model (inner weight) partial least square with bootstrap were used to test the hypothesis of study through the $t$-test and bootstrap stop, when the original and bootstrap estimate has a value that is close. The results of the original estimation and bootstrap estimation, $\mathrm{B}=500$ are presented in Figure 2. The complete model test results are seen from the $R$-Square value which illustrates the goodness-of-fit by a model. The recommended $R$-Square value was greater than zero and is presented in Table 3 . The result of the complete model test explains that the contribution or proportion of the PC, FP, FF variables in explaining variations around the SWB and QoL variable is 0.495 and 0.528 , respectively. The results indicate that all $\mathrm{R}$-square values are greater than zero, which indicates that this study model meets the required goodness of fit. Furthermore, value of Q2 = 1- (1- 0.495) $(1-0.528)=0.998$, indicates that the SWB and QoL models have high accuracy.

From the corresponding model in Figure 2, it is possible to interpret each path coefficient. The path coefficients are hypotheses in this study, which can be presented in the following structural equation:

$$
\begin{aligned}
& \mathrm{SWB}=0.151 \mathrm{PC}+0.263 \mathrm{FP}+0.141 \mathrm{FF} \\
& \mathrm{QoL}=0.183 \mathrm{PC}+0.158 \mathrm{FP}+0.243 \mathrm{FF}
\end{aligned}
$$

The results of the structural path coefficient (inner weight) along with the full significance values are shown in Table 4. Based on Table 4, the interpretation of each path coefficient is as follows:

1. Patient characteristics have a positive and significant effect on SWB. This is seen from the path coefficient which was positive at 0.151 with a statistical T-value of 3,770 that is greater than $\mathrm{t}$-table $=1.96$ from the significance level $(\alpha)$ determined at 0.05 . Therefore, $\mathrm{PC}$ has a direct effect of 0.151 on the SWB, which implies that every increase PC leads to a corresponding rise by 0.151 in SWB.

2. Patient factor has a positive and significant effect on SWB. This is evident from the positive marked path coefficient of 0.263 with a statistical T-value of 6.486 , which is greater than $\mathrm{t}$-table $=1.96$ of the significance level $(\alpha)$ determined at 0.05 . Therefore, the FP has a direct effect of 0.263 on SWB, which implies that every increase in FP, leads to a corresponding rise by 0.263 in the SWB.

3. Family factors have a positive and significant effect on SWB. This is evident from the positive marked path coefficient of 0.141 with a statistical T-value of 2.575 , which is greater than $\mathrm{t}$-table $=1.96$ of the significance level $(\alpha)$ determined at 0.05 . Therefore, the FF has a direct effect of 0.141 on SWB, which implies that any increase in $\mathrm{FF}$, leads to a corresponding rise by 0.141 in subjective well being.

4. Patient characteristics have a positive and significant effect on QoL. This is evident from the positive path coefficient of 0.183 with a statistical T-value of 4.310 , which is greater than t-table $=1.96$ of the significance levels determined at 0.05 . Therefore, PC directly affects the QoL by 0.183 , which implies that every increase in $\mathrm{PC}$, leads to a corresponding rise in the quality of life by 0.183 .

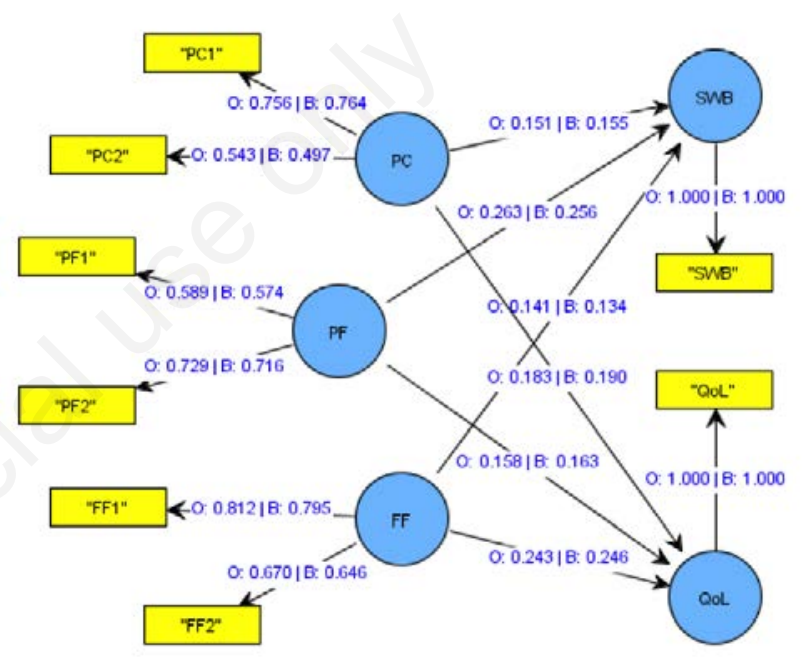

Figure 2. The connection of PC, FP, FF, SWB and QoL. PC, patient characteristics; FP, patient factor; FF, family factor; SWB, subjective well-being; QoL, quality of life.

Table 3. Goodness of fit from R-Square SWB and QoL.

Exogenous variables $\rightarrow$ Endogenous variables R-Square

Patient characteristics (PC), Patient factors (FP), Family factor (FF)

$\rightarrow$ Subjective well-being (SWB)

0.495

Patient characteristics (PC), Patient factors (FP), Family factor (FF) $\rightarrow$ Quality of life (QoL) 0.528

Table 4. Inner weight test on SWB and QoL with bootstrap samples $(B=500)$.

\begin{tabular}{lcccc} 
Exogenous variables $\rightarrow$ Endogenous variables & Coeff original & \multicolumn{3}{c}{$\begin{array}{c}\text { Sample bootstrap (B=500) } \\
\text { T-statistic }\end{array}$} \\
Information \\
Patient characteristics (PC) $\rightarrow$ Subjective well-being (SWB) & 0.151 & 0.155 & 3.770 & Significant \\
Patient factor (FP) $\rightarrow$ Subjective well-being (SWB) & 0.263 & 0.256 & 6.486 & Significant \\
\hline Family factor (FF) $\rightarrow$ Subjective well-being (SWB) & 0.141 & 0.134 & 2.575 & Significant \\
Patient characteristics (PC) $\rightarrow$ Quality of life (QoL) & 0.183 & 0.190 & 4.310 & Significant \\
\hline Patient factor (FP) $\rightarrow$ Quality of life (QoL) & 0.158 & 0.163 & 3.291 & Significant \\
Family factor (FF) $\rightarrow$ Quality of life (QoL) & 0.243 & 0.246 & 4.529 & Significant \\
\hline
\end{tabular}


5. Patient factor has a positive and significant effect on QoL. This is evident from the positive path coefficient of 0.158 with a statistical $\mathrm{T}$ value of 3.291 , which is greater than t-table $=1.96$ of the significance levels determined at 0.05 . Therefore, the FP directly affects the QoL by 0.158 , which implies that every increase in FP, leads to a corresponding rise in the quality of life by 0.158 .

6. Family factors have a positive and significant effect on QoL. This is evident from the positive path coefficient of 0.243 with a statistical $\mathrm{T}$ value of 4.529 , which is greater than t-table $=$ 1.96 of the significance levels determined at 0.05 . Therefore, the FF directly affects the QoL by 0.243 , which implies that every increase in FF, leads to a corresponding rise in the quality of life by 0.243 .

Family plays an important role in an individual's life because it is a system where there are family members interconnected and dependent on each other in providing support, love, security and attention and harmoniously carries out their respective roles to achieve common goals. The quality of the patient's family support system is one of the keys to successful management in pulmonary TB. The family plays a role in the psychological well-being of family members with regards to reduce stress and increase family resilience. Therefore, patients will be more likely to adhere to TB treatment. ${ }^{17}$ The results of this study showed that individuals with social support often have good quality, while those without social support sometimes have a poor quality of life. Furthermore, it presented that individuals with normal emotional conditions have a good quality of life, while those with mild stress have a poor quality of life. A patient's stress level is influenced by several factors, including source of stressors owned by the sufferer and family members, besides gender, age maturity and low levels of knowledge also affect emotional conditions, which directly has an effect on quality of life and subjective well-being.

Friedman's theory states that the family is the social unit that is most closely related to sufferers. ${ }^{18}$ Therefore, the implementation of family health care functions in good categories for the average respondent is to prevent health problems and/or care for sick family members. This implies that the family's ability to provide health care affects the health status of the family and the ability to carry out health care is seen from the family health duties.

Based on the results of this study, 47 respondents $(64.4 \%)$ were in the high subjective well-being category. The dominant factor that influences the SWB is the patient factor which includes emotional and social status. Bottom-Up theory states that life satisfaction that an individual feels and experiences depends on the amount of little happiness and a collection of events that make the individual happy. This assumption was based on that fact that occurrence of pleasant events is directly proportional to the happiness and satisfaction felt by an individual. According to Top-Down Theory, subjective well being experienced by an individual depends on the way he/she views and interprets an event in a positive light. This theory assumes that the individual is in control of every event experienced, whether the event will create psychological well-being or vice versa. Increasing subjective well-being requires efforts that focus on changing an individual's perception, beliefs and personality traits. ${ }^{19}$ Therefore, it is important to have a positive point of view, beliefs and thoughts in order to feel satisfied with life and often feel happy. Efforts to increase happiness should focus on how to change an individual's perspective, their beliefs with positive things and positive personality traits as well.

Furthermore, the results showed that most of the respondents, i.e. $50(68.5 \%)$ had a good quality of life and the dominant factor that affected the quality of life for pulmonary tuberculosis patients was family. Quality of life is an analysis concept of an individual's ability to obtain a normal life position in relation to perceptions of goals, expectations, standards and specific attention to life experienced by being influenced by values and culture in the environment the individual is in which is related to goals, expectations, their standards and concerns. ${ }^{20,21}$

Family factors and social support were other factors that could improve TB patients' quality of life. In addition to this, family factors which include stress, and the implementation of health care functions have a dominant influence on the quality of life of patients with pulmonary tuberculosis. This was explained in accordance with the theory which states that the family is not only a collection of family members, but also a context and a system and members of society. Therefore, in a certain context and system when a problem occurs it also affects family members. ${ }^{22,25}$

\section{Conclusions}

The results showed that by using PLS-SEM approach, the SWB and QoL structural models are fit models and the indicators on PC, FP and FF are valid and reliable. Furthermore, it showed that patient characteristics, patient factors and family factors influence subjective well-being and quality of life. In addition, the dominant influence on subjective well-being was the patient factor, while on quality of life it was the family factor.

Correspondence: Dhian Satya Rachmawati, Faculty of Public Health, Universitas Airlangga, Kampus C Mulyorejo Surabaya 60115, Indonesia.

Tel. +62.315920948 - Fax: +62.315924618 ,

E-mail: dhian.satya.rachmawati-2017@fkm.unair.ac.id

Key words: Quality of life; subjective well-being; pulmonary TB; family factors.

Contributions: All authors contributed equally during the study.

Conflict of interests: No potential conflict of interest.

Funding: This study was supported by Faculty of Public Health, Universitas Airlangga.

Acknowledgment: We would like to thank the Doctoral Program of Public Health, Faculty of Public Health, Universitas Airlangga who provided tremendous support during this study.

Ethical approval: A statement letter with Ethical Health Study Number: PE/69/VII/KEPK/SHT was obtained from the Health Research Ethics Committee of Stikes Hang Tuah, Surabaya, Indonesia.

Conference presentation: Part of this study was presented at the $1^{\text {st }}$ International Nursing and Health Sciences Symposium, November $13^{\text {th }}$ to $15^{\text {th }} 2020$, Brawijaya University, Malang, Indonesia.

Received for publication: 14 January 2021.

Accepted for publication: 15 March 2021.

oCopyright: the Author(s), 2021

Licensee PAGEPress, Italy

Journal of Public Health Research 2021;10:2180

doi:10.4081/jphr.2021.2180 


\section{References}

1. Chandra P, Singh S, Singh BK. Study of psychiatric co-morbidity in cases of tuberculosis patients undergoing treatment. Indian J Public Health Res Dev 2011;2:111-3.

2. Shen T, Wang C, Lin C, et al. People with tuberculosis are associated with a subsequent risk of depression. Eur J Intern Med 2014;25:936-40.

3. Lee LY, Tung HH, Chen SC, et al. Perceived stigma and depression in initially diagnosed pulmonary tuberculosis patients. J Clin Nurs 2017;26:4813-21.

4. Samal J, Dehury RK. Role of families in tuberculosis care: A case study. Muller J Med Sci Res 2016;7:150-2.

5. Kaulagekar-Nagarkar A, Dhake D, Jha P. Perspective of tuberculosis patients on family support and care in rural Maharashtra. Indian J Tuberc 2012;59:224-30.

6. WHO. Global Tuberculosis Report. Geneva: World Health Organization; 2017. Available from: https://www.who.int/tb/ publications/global_report/gtbr2017_main_text.pdf?u $\% 20 \mathrm{a}=1$

7. Ministry of Health, Republic of Indonesia. Health Profile of Indonesia. Jakarta: Ministry of Health Republic of Indonesia; 2016.

8. Public Health Office of Surabaya. Health Profile 2015. Surabaya: Public Health Office of Surabaya; 2015.

9. Ramadhan I, Budiarti LY, Lestari DR. [Tingkat Pengetahuan Dengan Mekanisme Koping Penderita Tuberculosis Paru (Knowledge level with coping mechanisms for patients with pulmonary tuberculosis)].[Article in Indonesian]. Dunia Keperawatan: Jurnal Keperawatan dan Kesehatan 2013;1:807.

10. Sedjati F. [Hubungan Antara Efikasi Diri Dan Dukungan Sosial Dengan Kebermaknaan Hidup Pada Penderita Tuberkulosis Paru Di Balai Pengobatan Penyakit Paru-Paru (BP4) Yogyakarta (The relationship between self-efficacy and social support with meaningful life for patients with pulmonary tuberculosis at the center for lung disease treatment (BP4) Yogyakarta)].[Article in Indonesian with English Abstract]. EMPATHY Jurnal Fakultas Psikologi 2013;2. Available from: http://garuda.ristekbrin.go.id/documents/detail/123266

11. Ardiansyah M. [Medikal Bedah Untuk Mahasiswa (Medical surgery for students)].[Book in Indonesian]. Yogyakarta: DIVA Press; 2012.

12. Mahmudah U, Cahyati WH, Wahyuningsih AS. [Analisis Kualitas Penggunaan Buku Kesehatan Ibu Anak (Analysis of the quality of use of maternal child health books].[Article in Indonesian]. Jurnal Kesehatan Masyarakat 2013;8:113-20.

13. Nasution SD. [Malnutrisi Dan Anemia Pada Penderita
Tuberkulosis Paru (Malnutrition and anemia in patients with pulmonary tuberculosis)].[Article in Indonesian]. Majority 2015;4:29-36.

14. Saraswati R, Hasanah N, Ummah MBA. [Konsep Diri Penderita Tb Paru Di Rs Pku Muhammadiyah Gombong (Selfconcept of pulmonary tuberculosis patients at Rs Pku Muhammadiyah Gombong)].[Article in Indonesian]. Jurnal Ilmiah Kesehatan Keperawatan 2016;12:91-101.

15. Hastuti ID, Setiawan R, Fikri J. [Hubungan Dukungan Sosial Dengan Kualitas Hidup Pada Penderita Tuberkulosis Paru Di Balai Kesehatan Kerja Masyarakat Provinsi Jawa Barat Tahun 2014 (The relationship between social support and quality of life for patients with pulmonary tuberculosis at the community occupational health center of West Java Province in 2014)].[Article in Indonesian]. Bhakti Kencana Medika 2014;4:1-74.

16. Chin WW. The partial least squares approach to structural equation modeling. In: G.A. Marcoulides, editor. Modern methods for business research. Mahwah: Lawrence Erlbaum Associates; 1998. pp. 295-336.

17. Rachmawati DS, Priyantini D, Aini Q. Family factors and their relation to the treatment adherence of pulmonary TB patients in Surabaya. Jurnal Ners 2020;15:45-9.

18. Friedman MM. [Buku Ajar Keperawatan Keluarga Riset, Teori, \& Praktik (Textbook of Family nursing research, theory, \& practice].[Book in Indonesian]. Jakarta: EGC; 2010.

19. Diener E. Subjective well-being. The science of happiness and a proposal for a national index. Am Psychol 2000;55:34-43.

20. Nursalam. [Metodologi Penelitian Ilmu Keperawatan (Nursing Research Methodology)].[Book in Indoensian]. Jakarta Selatan: Salemba Medika; 2015.

21. WHO. WHOQOL: Measuring quality of life. Geneva: World Health Organization; 1997. Available from: https://www.who.int/tools/whoqol

22. Kaakinen JR, Duff VG, Coehlo DG, Hanson SMH. Family health care nursing. 5th ed. Philadelphia: F.A. Davis Company; 2015.

23. Aggarwal AN. Quality of life with tuberculosis. J Clin Tuberc Other Mycobact Dis 2019;17:100121.

24. Salehitali S, Noorian K, Hafizi M, et al. Quality of life and its effective factors in tuberculosis patients receiving directly observed treatment short-course (DOTS). J Clin Tuberc Other Mycobact Dis 2019;15:100093.

25. Sukartini T, Hidayati L, Khoirunisa N. Knowledge, family and social support, self-efficacy and self-care behaviour in pulmonary tuberculosis patients. Jurnal Keperawatan Soedirman 2019;14:114-25. 